\title{
David Ellis, D.Sc.
}

Dr David Ellis, Professor of Bacteriology in the Royal Technical College, Glasgow, died suddenly in his home at Bearsden on January I6, 1937, aged sixty-two years. Less than three months previously he had suffered severe bereavement through the death of his wife. He was a native of South Wales and was educated at the University College of Wales, Aberystwyth, and graduated in I 896 at the University of London. For some time he taught as a science master at secondary schools, and then proceeded to the University of Marburg, where he gained the degree of Ph.D. in I902 for researches in bacteriology. After his return to this country he studied at the Lister Institute, London, and later took up science teaching at Dollar Academy. In 1904 he was appointed lecturer in bacteriology and botany in the Glasgow and West of Scotland Technical College, now the Royal Technical College, Glasgow.

Ellis obtained the degree of D.Sc. of the University of London in 1905 for his researches in mycology. His further work on fungi was concerned principally with fossil species.

In I9I 5 he published a paper dealing with the occurrence of fossil fungi and bacteria in slides prepared from ironstones and ferruginous limestones from various districts in Great Britain, and in 1917 he described certain phycomycetous fungi found in tissues of Lepidodendron and Lyginodendron which, it is suggested, are related to the modern Peronosporaceæ; both these papers appeared in the Proceedings of the Royal Society of Edinburgh.

From 1907 to 1919 he was a lecturer in nature study to the Glasgow Provincial Committee for the Training of Teachers, and was for some time lecturer in technical mycology in the University of Glasgow. He took a great interest in adult education, and his popular lectures in botany attracted large audiences. His publications include $A$ Guide to the Common Wild Flowers of the West of Scotland, $A$ Guide to the Common Wild Flowers in Wales, A Guide to the Study of Nature (1912), and Medicinal Herbs and Poisonous Plants (1918). He was a frequent attendant at meetings of the British Association, where on several occasions he read papers on bacteriological subjects. For many years he acted as chief examiner in botany for the Central Welsh Board.

Since I920 Professor Ellis also held the post of Superintendent of the School of Pharmacy and the Scottish School of Bakery at the Royal 
Technical College, and in the latter capacity he showed a marked gift for the expression of scientific subjects in simple language. His work covered a wide field, and during this period he published (with $\mathrm{D}$. Campbell) The Science and Practice of Confectionery (1928) and A Science Course for Bakers (1923). Bacteriology was, however, his chief study, and his publications include books on the Outlines of Bacteriology, Practical Bacteriology for Chemical Students (1923), and several contributions to the knowledge of Cladothrix and Leptothrix.

$\mathrm{He}$ is widely known for his work on the iron and the sulphur bacteria, on each of which subjects he published a monograph. The iron bacteria form an important group, which is one of the makers of geological history, for many of the bog iron ores owe their formation largely to the activities of these organisms. They are of importance to the water engineer in relation to water reservoirs, the corrosion of pipes, and the general appearance and clarity of waters. Six species were fully described in the monograph which appeared in I9I9. In the monograph on the sulphur bacteria published in 1932 Professor Ellis paid much attention to the classification of the group and adopted an original scheme based on a division into colourless forms and coloured forms, the rhodo-theio-bacteria; a very complete account was given of the colouring matter of these latter organisms. The sulphur metabolism of the group was described, and the important part played by these organisms in nature fully discussed.

Professor Ellis was an expert on problems relating to the disposal of sewage, and several of his publications such as The Sulphur Bacteria as Aids in the Study of Polluted Waters and The Blackening of the Sand of the Clyde Estuary deal with this subject. He frequently acted as consultant in law cases when water pollution led to litigation. He was also consulted by Government departments, including the Department of Health, on this and kindred subjects.

He was keenly interested in the work of the Royal Philosophical Society of Glasgow, and at the time of his death was president of the Biological Section. His leisure time was divided between golf, cycling, and the care of his garden, and it was while employed in his garden that he died.

He was elected a fellow of the Society in 1906.

M. W. 